DERLEME - REVIEW

\title{
Teniste Beslenme
}

\section{Nutrition in Tennis}

\section{Neşe Toktaş ${ }^{1}$, Rabia Demirörs ${ }^{2}$}

Geliş tarihi/Received: 31.01.2020 • Kabul tarihi/Accepted: 05.10.2020

\section{ÖZET}

Genetik, fizyolojik, psikolojik, çevresel faktörler, sağlık, antrenman durumu gibi birçok faktör sporcunun performansını etkilemektedir. Doğru beslenmenin de üst düzey performansa ulaşmada önemli olduğu tartışmasızdır. Spor branşının gereksinimi doğrultusunda, sporcunun antrenman planına uygun, hedefe yönelik, bireyselleştirilmiş bir beslenme programı antrenmana adaptasyonu sağlama, performansı arttırma, toparlanmayı hızlandırma, yaralanma riskini azaltma ve hastalıkları önleme üzerinde önemli bir etkiye sahiptir. Spor branşına özgü bireysel beslenme programının oluşturulabilmesi için spor branşının fizyolojik gereksinimleri iyi anlaşılmalıdır. Mevcut literatürde genel beslenme önerileri yer almakta, branşa özgü öneriler yetersiz kalmaktadır. Bu derleme makalede, güncel bilgiler ışığında iyi bir spor performansı için tenisçilerin; enerji, makro ve mikro besin ögesi gereksinimlerine değinilmiş, tenisçiler için beslenme stratejilerinden bahsedilmiştir.

Anahtar kelimeler: Tenis, beslenme, spor performansı

\begin{abstract}
Many factors such as genetic, physiological, psychological, environmental factors, health, training status affects the performance of the athlete. It is indisputable that proper nutrition is also important in achieving high performance. In line with the needs of the sports branch, the creation of a nutrition program suitable for the athlete's training plan, purpose and personalization has a significant impact on adaptation to training, improve performance, accelerate recovery, reduce the risk of injury and prevent disease. In the current literature, general nutrition recommendations are included and these recommendations are insufficient for branch-specific recommendations. In this review article, energy, macro and micronutrient requirements of tennis players are discussed for good sport performance in light of current knowledge and nutritional strategies for tennis players.
\end{abstract}

Keywords: Tennis, nutrition, sport performance

1. Akdeniz Üniversitesi, Spor Bilimleri Fakültesi, Antrenörlük Eğitimi Bölümü, Spor Sağllk ABD, Antalya, Türkiye • • https://orcid.org/0000-0002-3206-6536
2. ̇letişim/Correspondence: Akdeniz Üniversitesi, Sağllk Bilimleri Enstitüsü, Hareket ve Antrenman ABD, Antalya, Türkiye

E-posta: rabiademirors@gmail.com • ๑ https://orcid.org/0000-0002-4410-5782 


\section{GíRiş}

Tenis, katılım düzeyine göre dünya çapında en popüler sporlardan biridir. Çocukluktan yaşlılığa kadar her iki cinsiyette ve her yaşta çeşitli beceri (başlangıç, orta, ileri, elit ve profesyonel) seviyelerinde oynanmaktadır (1). Profesyonel tenis yll boyunca dünya genelinde 33 ülkede oynanmakta ve Grand Slam turnuvalarında şampiyon, iki haftaya yayılan yediden fazla maç ile belirlenmektedir. Oyuncular bu nedenle her iki günde bir kadınlar için 3 set ve erkekler için 5 set arasında değişen maçlar oynamaktadır. Hatta bazı oyuncular, uygun olmayan hava koşulları nedeniyle maçların ertelenmesinden veya birden fazla kategoride rekabet etmelerinden dolayı (tekler, çiftler, karışık çiftler) her gün müsabakaya katılabilmektedirler (2). Tenis süre tabanlı değil, puanlamaya dayalı bir spordur. $\mathrm{Bu}$ nedenle maç süreleri önemli ölçüde değişebilmektedir. Ayrıca, hem iç hem de dış mekânlarda ve çok çeşitli çevresel koşullarda çeşitli kort yüzeylerinde oynanmaktadır (1). Tenisçilerin fizyolojik gereksinimlerini anlayarak daha iyi adaptasyon oluşturmalarını sağlamak iyi bir performans gösterebilmeleri için önemlidir. Sportif performans birçok faktörün etkileşimine bağlıdır (3). Sporcuların en iyi performansı gösterebilmeleri için daha iyi fizyolojik adaptasyonlar oluşturmak, doğru beslenmeyi sağlamak, performansı sınırlayan faktörleri kontrol etmek, maçlar ve antrenmanlardan sonra iyi bir toparlanma sağlayacak stratejiler uygulamak önemlidir (4). Sporcunun beslenmesi antrenmana adaptasyonu sağlama, performansı arttırma,toparlanmayıhızlandırma, yaralanma riskini azaltma ve hastalıkları önleme üzerinde doğrudan bir etkiye sahiptir. Fleming et.al'un (5) derleme makalesinde, diğer spor dallarındaki sporcuların beslenme alışkanlıkları ve beslenme bilgisi ile ilgili çalışmaların yer aldığı, ancak tenis sporcularında yapılan çalışmaların yetersiz olduğu belirtilmektedir. $\mathrm{Bu}$ derleme makalede, güncel literatür eşliğinde, iyi bir sportif performans için tenisçilerin enerji, makro ve mikro besin ögesi gereksinimlerinin, beslenme stratejilerinin açıklanması amaçlanmıştır.

\section{Tenisçilerin Fiziksel ve Fizyolojik Özellikleri}

Tenis, hız, çeviklik, kuvvet ve aerobik dayanıklılığın yanı sıra öngörü, hızlı reaksiyon ve stratejik düşünme kapasitesi gerektirmektedir (6). Kısa süreli ve yüksek şiddetli, tekrarlayan dinamiklerle interval bir spordur ve çeşitli vücut pozisyonlarında hızlanma, yavaşlama, esneme, sıçrama, vuruş yapma gibi hızlı ve patlayıcı hareketler gerektirir $(5,7)$. Bir tenis maçı normalde 1.5-2 saat sürer ancak 5 saate kadar da uzayabilir. Bu süre boyunca vücuda büyük mekanik ve fizyolojik stres uygulanır $(5,8)$. Genel olarak bir puan alımı 5-10 sn sürmekte ve puanlar arasında 20 sn'lik bir mola bulunmaktadır. Kort değişimleri sırasında mola 60 ile 120 sn arasında değişir (8). Top ve raket arasındaki temas süresi 0.003-0.006 sn arasındadır. Vuruşun gerçekleştirilebilmesi için raketin ve topun en uygun yönde olması gerekir. Bu nedenle, üst düzey bir tenis oyunu uzun süre boyunca yüksek konsantrasyon da gerektirir (9).

Çoğunlukla hızlı kasılan tip iki kas lifine sahip olması gereken sprinterler veya haltercilerden ya da yavaş kasılan tip bir kas liflerinin çoğunluğuna sahip olması gereken dayanıklılık sporcularından farklı olarak, tenis oyuncularmda her iki kas lifinin de optimum düzeyde bulunduğu belirlenmiştir. Tenis sporu, hız, çeviklik ve güç gibi anaerobik becerilerin, yüksek aerobik yeteneklerle bir arada kullanılmasına ihtiyaç duyar (9).

Kas ve karaciğer glikojen depoları şiddetli antrenman ve/veya maçlar sırasında tükenebilir bu da enerji yetersizliği nedeniyle performansı olumsuz yönde etkiler. Ayrıca, antrenman ve/veya maç sırasında pH'daki azalma, fosfojen sistem ve kas kasılması yoluyla enerjide bir düşüşe ve subjektif algıda bir artışa neden olabilir (4).

Tenisçilerde tekler karşılaşması sırasında ortalama kalp atım hızının 141-182 atım/dk arasında değiştiği ve bunun maksimum kalp atım hızının \%70-90'ına karşılık geldiği görülmüştür (10). Kalp atım hızı, oyun süresi içerisinde ve kort yüzeyleri gibi faktörlere bağlı 
olarak değişkenlik gösterebilmektedir. Maçın bazı bölümlerinde bu değerin dakikada 190-200 atıma ulaşabileceği belirtilmektedir (7).

Tenis oyuncularının maksimum oksijen tüketim $\left(\mathrm{VO}_{2 \max }\right)$ değeri yüksektir. Profesyonel tenisçilerin tenis kortunda uygun bir performans göstermeleri için $\mathrm{VO}_{2 \max }$ değerlerinin $>50 \mathrm{~mL} / \mathrm{kg} / \mathrm{dk}$ olması önerilir (9). Oyun sirasindaki ortalama oksijen tüketimi 23.1 $( \pm 3.1)$ ile $40.3( \pm 5.7) \mathrm{mL} / \mathrm{kg} / \mathrm{dk}$ arasında değişmekte ve bunun da maksimum oksijen tüketim kapasitesinin \%50 ile \%80’ini yansıttığı belirtilmektedir (10).

Kan laktat düzeyi, egzersiz sırasında anaerobik glikolizin enerji üretimindeki katkısını belirlemek için önemli bir bulgudur. Tenis sporunda kan laktat düzeyinin yüksek olmadığı ancak 4-5 mmol/L, hatta profesyonel sporcular için $8 \mathrm{mmol} /$ L’ye kadar yükselebileceği de belirtilmektedir. Profesyonel olmayan sporcularda ise bu değer $10 \mathrm{mmol} / \mathrm{L}$ ye kadar ulaşabilir. $\mathrm{Bu}$ değerlere rağmen, ortalama kan laktat konsantrasyonunun tenis oyuncularında antrenman/maçlar sırasında yaklaşık 2-4 mmol/L olduğu belirtilmektedir (7).

Tenis oyuncularının vücut yağ yüzdeleri atletizm ve jimnastik sporcuları kadar olmasa da genel popülasyona göredüşüktür(9). Genç oyuncularınvücut yağ yüzdesinin yaklaşık \%13 olduğu görülmektedir. Oyuncuların antrenman ve müsabakaya katılımının artmasılyla birlikte bu değer \%8-10'a kadar düşme eğilimindedir (7). Tenis oyuncularında optimal vücut yağ yüzdesi değerinin erkeklerde \%12, kadınlarda \%23’ün altında olması önerilmektedir (9).

\section{Teniste Enerji, Makro ve Mikro Besin Ögeleri Alım Önerileri}

Beslenme; sporcuların antrenman adaptasyonlarını, performansını arttırma, toparlanma süresini hızlandırma, yaralanma ve hastalık riskini önleme üzerinde doğrudan bir etkiye sahiptir (5). Oyunun oynandığı yüzey, oyun tarzı, çevre koşulları, sürekli seyahat, büyüme ve gelişme, tenisçilerin fizyolojik ve beslenme ihtiyaçlarını etkileyen faktörlerden bazılarıdır (2). Düzenli olarak turnuvalara katılan oyuncular için hızlı bir şekilde toparlanmak, ertesi gün veya daha sonra veya aynı gün tekrar oynayabilmeleri için elzemdir (11). Tenisçilerin her maçtan önce yeterince enerji ve sıvı aldıklarından emin olunmalıdır. Ancak maçın ne kadar süreceği önceden bilinmediği için bu durum zorlaşır. Ayrıca bir turnuvada oyunun gecikmeli başlaması veya oyuncunun günde birden fazla müsabakasının olması yetersiz beslenmeye veya midede henüz sindirilmemiş besinlerle maça çıkılmasına yol açabilir. Ayrıca beklenmeyen bir sonuç ya da turnuvadan erken çıkma, sporcunun hazırlıkları sırasında fazla besin almış olmasına neden olabilir. Bu nedenle oyuncular, performansını üst düzeye çıkarabilmek için bir spor diyetisyeninden/beslenme uzmanından rehberlik almalıdır (12).

Enerji: Teniste kort yüzeyinin türü, oyun tarzı (servis ve vole, taban çizgisi oyuncusu), mücadele süresi, oyun aşaması (servis ya da dönüş), ortam sıcaklığı, nem gibi birçok faktör fizyolojik gereksinimleri karmaşı hale getirmekte ve enerji ihtiyacını etkilemektedir $(12,13)$. Örneğin toprak kortta oynayan oyuncular, çim korttaki oyunculara göre servis ve vole vuruşlarını daha çok kullanmaktadır. Bu da toprak kortta oynanan oyunlarda topun gidip gelme (rally) sayısının daha çok olmasına neden olmaktadır. Bu nedenle toprak kortta oynayan tenisçiler daha fazla enerji harcarlar (12).

Sezon boyunca, oyuncunun antrenman programına veya bir turnuvadaki farklı turlara bağlı olarak, enerji ihtiyacındaki büyük değişkenlik göz önünde bulundurulduğunda, belirli bir vücut ağırlığını korumak tenisteki zorluklardan biridir (4). Elit standartlardaki tenis oyuncularının tüm yıl boyunca en uygun vücut ağırlıklarını ve bileşimlerini sürdürmeleri ve böylece kısa süreli dinlenme veya seyahat dönemlerinde enerji alımlarını ayarlamaları gerekir (12).

Yapılan bir çalışmada; 9-12, 13-15, 16-18 yaşları arasındaki genç tenis oyuncularının antrenman ve müsabakadaki enerji harcamaları karşılaştırılmış; yaştan bağımsız olarak, 9-18 yaş aralığındaki 
oyuncuların müsabakalarda antrenmana göre daha fazla enerji harcadığı gösterilmiştir. Ayrıca aynı makalede maç ve antrenman süresince, gençlerin metabolik eşdeğer (MET) değerlerinin yetişkinlere göre daha düşük olduğu, bu farklılığın 16-18 yaş gibi yetişkinliğe yakın dönemlerde ortadan kalktığı, bu yüzden 16 yaşın altındaki bireylerde yetişkin MET değerlerinin kullanılmaması gerektiği belirtilmiştir. MET kişinin oturur durumda, istirahat halindeyken kullandığı oksijen miktarıdır ve $1 \mathrm{MET}=3.5 \mathrm{~mL} / \mathrm{kg} /$ dk'dır (14).

Uluslararası Tenis Federasyonu'na (International Tennis Federation-ITF) göre çoğu oyuncunun günlük enerji ihtiyacı 2500 kkal civarındadır ancak bazı oyuncular için bu 3000 kkal'ye kadar çıkabilir. Profesyonel tenisçilerin günlük enerji gereksinimlerinin ise $3500 \mathrm{kkal}$ ile $5000 \mathrm{kkal}$ arasında olduğu tahmin edilmektedir (15). Tenisçilerde cinsiyete ve maç süresine göre tahmini enerji harcaması Tablo 1’ de gösterilmiştir (12).

Karbonhidrat: Karbonhidrat kaslara, beyin ve organlara yakıt sağlayan en iyi enerji kaynağıdır. Vücutta glikojen formunda depolanır (11). Glikojen günümüzde sadece bir enerji substratı değil, aynı zamanda egzersize cevap olarak uyarıları düzenleyen sinyal yolaklarının da düzenleyicisi olarak kabul edilmektedir (16). Glikojen depolarını yenilemek karbonhidrat alımında temel hedeftir. Sürantrene (aşırı antrenman olumsuzluğu) olmamak ve bağışıklık sisteminin işlevi için de karbonhidrat alım miktarı önemlidir. Bağışıklığın azalması, glikojen depolarının azalması ile yakından ilişkilidir, ayrıca sitokin ile kortizol düzeylerinin artmasına neden olur (4). Tenisçilerin optimum performans için glikoz ve glikojen depolarinı uygun konsantrasyonlarda tutmaları gerekir (17).

Uluslararası Tenis Federasyonu'na göre karbonhidratlar günlük alınan enerjinin yaklaşık \%60'ını oluşturmalıdır (15). Karbonhidrat gereksinimi egzersizin türüne ve yoğunluğuna bağlı olarak büyük ölçüde değişiklik gösterir. Günlük gereksinim ve toparlanma ihtiyacına göre hafif şiddetli egzersizlerde 3-5 g/kg/gün, orta şiddetli egzersizlerde 5-7 g/kg/gün, yüksek şiddetli egzersizlerde 6-10 g/ kg/gün karbonhidrat tüketimi önerilmektedir. Çok yüksek şiddetli egzersizlerde ise karbonhidrat alımı günde 8-12 g/kg’a arttırılabilir $(18,19)$. Standart bir karbonhidrat alımından ziyade sporcunun antrenman programı, müsabaka dönemi, enerji gereksinimi, amacı, performansı gibi birçok faktöre bağlı olarak karbonhidrat alımının bireyselleştirilmesi, hedeflerin sporcuya özgü olması gerektiği belirtilmektedir $(19,20)$. Genel olarak elit standartlardaki tenisçiler, dayanıklılığı devam ettirmek, sitokin ve kortizol düzeyindeki artışı azaltmaya yetecek yeterli glikojen deposunu sağlayabilmek için 6-10 g/kg/gün olacak şekilde yüksek karbonhidrat içeren beslenme programı uygulamalıdır $(4,11,12)$. Kadın sporcuların gereksinimi erkek sporculardan biraz daha azdir. Ayrıca bu öneri günlük enerji harcamasına uyacak şekilde planlanmalıdır $(11,12)$. Düşük karbonhidratlı bir diyetin (toplam enerji alımının <\%15'i) tenis maçının kilit unsurları olan yüksek şiddetli egzersiz ve dayanıklılık performansını etkileyebileceği de bilinmektedir (12).

Tablo 1. Tenisçilerde cinsiyete ve maç süresine göre tahmini enerji harcaması ( \pm standart sapma) (12).

\begin{tabular}{lll}
\hline & Kadın & Erkek \\
\hline $\mathrm{kj} / \mathrm{dk}$ & $30.9(5.5)$ & $45.3(7.3)$ \\
$\mathrm{kkal} / \mathrm{dk}$ & $7.4(1.3)$ & $10.8(1.8)$ \\
$\mathrm{kkal} / \mathrm{kg} / \mathrm{saat}$ & $7.5(0.5)$ & $8.4(0.5)$ \\
$60 \mathrm{dk}$ maç (kkal) & $443(79)$ & $649(105)$ \\
$90 \mathrm{dk}$ maç (kkal) & $664(118)$ & $973(157)$ \\
$150 \mathrm{dk}$ maç (kkal) & $1107(196)$ & $1622(262)$ \\
$300 \mathrm{dk}$ maç (kkal) & - & $3244(524)$ \\
\hline
\end{tabular}


Egzersiz öncesi tüketilen karbonhidrat özellikle gece boyu boşalan karaciğer glikojen depoları olmak üzere vücut glikojen depolarını arttırmakta ve aynı zamanda aktivite süresince bağırsak glikoz salınımının kaynağı olabilmektedir (19). Sporcuların egzersizden 1-4 saat önce, 1-4 g/kg karbonhidrat almaları önerilir ancak, aşırı alım da performansı olumsuz yönde etkileyebilir. Bunun nedeni genellikle insülin yanıtının metabolik etkisinin (yağ mobilizasyonunda azalma ve karbonhidrat kullanımında artış) erken yorgunluğu tetiklemesidir (16). Egzersiz sırasında karbonhidrat alımı; glikojen oksidasyonu, glisemik denge ve depolardaki glikojenin ekonomik kullanımı için avantaj sağlar. Saatte $0.5 \mathrm{~g} / \mathrm{kg}$ karbonhidrat alındığında glisemik dengenin korunmasına ek olarak efor nedeniyle hissedilen subjektif alginin ve kortizole verilen yanıtın da daha düşük olduğu ifade edilmektedir (4). Kırk beş dakikadan kısa süren egzersizler sırasında ek karbonhidrat alımına ihtiyaç olmamakla birlikte 45-75 dakika yapılan sürekli ve yüksek yoğunluklu egzersizler sırasında az miktarda karbonhidrat alımı veya ağızda çalkalama stratejisi uygulanabilir. Egzersiz süresi 1-2.5 saat olduğunda genel olarak 30-60 g/saat karbonhidrat tüketimi, 2.53 saatten uzun süren ultra dayanıklılık egzersizleri sirasında ise $90 \mathrm{~g} / \mathrm{saat}$ karbonhidrat tüketimi önerilmektedir (19). Egzersiz sonrası toparlanma süresinin başlarında (ilk 4-6 saat boyunca) 1-1.2 $\mathrm{g} / \mathrm{kg} / \mathrm{saat}$ karbonhidrat tüketiminin, egzersizler arasındaki glikojen depolarının doldurulma süresinin kısalmasında etkili olduğu gösterilmiştir $(18,19)$. Glikojen sentez kapasitesi, egzersizden 30-60 dakika sonra daha fazladır, egzersiz sonrası bir saat boyunca $1 \mathrm{~g} / \mathrm{kg}$ yüksek glisemik indeksli karbonhidrat alımı önerilir. Ayrıca, bu etkiyi arttırmak için protein eklemeyi ve karbonhidrata eşlik eden proteinin yüksek kalitede bir protein kaynağı olması gerektiğini belirtmektedir (4).

Protein: Proteinler 4 kkal/g (17 kj/g) enerji sağlayan ve amino asitlerden oluşan temel besin ögeleridir. Amino asitler, insan vücudunun yapı taşlarıdır. Hücrelerin, kasların, organların, hormonların yapısında bulunurlar ve bağışıllık faktörlerinin sentezlenmesi için kullanılırlar (21). Protein kas ve doku onarımı için çok önemlidir. Sahadaki ideal enerji kaynağ 1 değildir, ancak glikojende bir azalma ya da kortizolde bir artış olduğunda enerji üretimi için kullanılırlar $(4,11)$. Tenis hem dayanıklılık hem de güç sporudur. Tenise özgü protein gereksinimi antrenman ya da müsabakanın hacmine ve yoğunluğuna uygun olarak belirlenmelidir (12).

Her gün yüksek yoğunlukta antrenman yapan tenisçilerin $1.6 \mathrm{~g} / \mathrm{kg} / \mathrm{gün}(11,12)$ ile $1.8 \mathrm{~g} / \mathrm{kg} / \mathrm{gün}$ (22) protein tüketmeleri önerilir. Bu protein miktarı elit bir tenisçi için artan enerji ihtiyacını karşlayacak yüksek enerjili bir diyet ile besin desteği kullanmadan sağlanabilir. Kadınların enerji gereksinimi erkeklerden daha düşük olduğu gibi protein ihtiyaçları da daha azdır (12). Enerji kısıtlamasının olduğu dönemlerde yağsız doku kütle kaybını önlemek amacıyla protein miktarı günde 1.8-2.0 g/kg’a çıkartılabilir $(19,22)$. Antrenman veya maçları takip eden 24 saatlik süre boyunca doğru zamanlanmış bir dağılımla yüksek kaliteli protein alımının önemli olduğu belirtilmektedir. Yüksek kaliteli proteinler bir öğünde 0.3-0.4 g/kg olmak üzere günde 4-5 öğün tüketilmelidir. Kas protein sentezinin baskılandığı, düşük enerji alımı veya vücut ağırlık kaybı hedefinin söz konusu olduğu durumlarda bu miktar bir öğünde 0.4-0.5 g/kg olmak üzere günde 4-5 öğün tüketilmelidir (23).

Tenisçilerin antrenmandan/maçtan 30 dakika sonra sindirimi kolay protein tüketmeleri önerilmektedir (11). Antrenman sonrası toparlanmayı en üst düzeye çıkarmak için yaklaşık 8-10 g esansiyel amino asit sağlayan, yaklaşık 20-25 g yüksek kaliteli protein alımı gerekir. Egzersiz sonrası protein, kas protein sentezinin en fazla uyarıldığı 0-4 saatlik bir süre içinde alınabilir (24). Dikkate alınması gereken bir diğer önemli husus, protein kaynağının kalitesidir. Sporcular yeterli miktarda esansiyel amino asit elde etmek için biyolojik değeri yüksek protein tüketmelidir. Hayvansal özellikle de süt bazlı proteinler, bitkisel proteinler ile karşılaştırıldığında daha fazla esansiyel amino asit içeriğine ve daha yüksek anabolik etkiye sahiptir. Yeterli lösin (700- 
3000 mg) içeren hızlı sindirilen kaliteli proteinler kas protein sentezini uyarmada en etkili proteinlerdir (25). Sığır, tavuk ve hindi etleri, yumurta, yoğurt kaliteli protein kaynaklarına örnek olarak verilebilir (24).

Yağ: Karbonhidrat teniste kullanılan öncelikli yakıt kaynağı olmasına rağmen, özellikle maç veya antrenmanın süresi arttıkça, yağ oksidasyonu enerji oluşumuna katkıda bulunur (11). Yağlar, hücre zarlarının ana yapısal bileşeni olarak ve enerji depolamak için vücutta kritik rol oynarlar (21). Sporcular tarafından yağ alımı toplum sağlığı önerilerine uygun olmall, antrenman düzeyi ve vücut kompozisyonu hedeflerine göre bireyselleştirilmelidir (19). Teniste yağ alımı için özel bir gereklilik olmamasına rağmen, yağda çözünen vitaminler ve esansiyel yağ asitlerinin minimum gereksinimlerine ulaşmak açısından yağ alımı önemlidir (4). Uluslararası Tenis Federasyonu'na göre, yağlar günlük enerjinin yaklaşık \%20-30’unu (en az 30-40 g/ gün) oluşturmalı, elit oyuncuların enerji ihtiyaçlarını karşılamak için günde 80-100 g olmalıdır (15). Uzun süreli günlük enerjinin \%20'sinin altında yağ alımı, yağda çözünen vitaminler ve esansiyel yağ asitleri gibi çeşitli besin ögelerinin alımını azaltmasından dolayı önerilmemektedir (19).

\section{Sivı/Elektrolitler/Mineraller:}

Oyuncularm genellikle sıcak ve nemli ortamlarda rekabet ettiği tenis gibi sporlarda, sıvı ve elektrolit dengesi optimum performans için önemli bir faktördür $(4,11)$. Sicak ortamlardaki egzersiz sirasinda terlemenin artışıyla birlikte eğer yeterli sıvı alınmazsa terlemeye aşamalı olarak dehidrasyon da eşlik eder (6). Vücut ağırlığının >\%2-3’üne eşdeğer sıvı kayıpları, algılanan zorluk derecesinde artış, plazma hacminde azalma, termoregülasyon, kardiyak işlevler ve performansta bozulma ile ilişkilidir (23). Tenis performansının önemli bileşenleri olan aerobik performans, postural denge, bilişsel performans, ruh hali ve zihinsel performans dehidrasyondan olumsuz olarak etkilenir (26).

Şiddetli sıvı kaybı ile dolaşımdaki kan hacmi azalır, bireyin maksimum potansiyel kardiyak çıtısı tehlikeye girer ve kanın çalışan kaslara, cilde ve beyne akışı kısıtlanır. Beyne kan akışının azalması; zihinsel, bilişsel becerilerde ve performansta düşüşe, hatalara ve takım çalışmalarının bozulmasına neden olabilir (27). Böylece egzersiz sırasında sürdürülebilir güç üretimi azalır ve $\mathrm{VO}_{2 \max }$ düşer (6).

Tenisçiler sıcaklık, nem, sıvı alım miktarı, çevresel özellikler, maç şiddeti gibi çeşitli faktörlere bağlı olarak müsabaka boyunca 0.5-1.5 kg arasinda vücut ağırlığı kaybederken, ter kaybı saatte 0.5-3 L arasında olabilir (7). Terleme oranları yüksek olan tenisçiler saatte yaklaşık \%2.3-2.7 kg sıvı kaybedebilir (4). Sıvı dengesini ve homeostazı sağlamak, optimal vücut işlevini, egzersiz performansını ve sağlığı korumak için sık sık (her 10-15 dakikada bir) su veya spor içeceği tüketilmelidir (28). Tenisçi egzersizden önceki dört saatte 5-7 mL/kg sıvı almalıdır. Sporcu hala idrara çıkmıyorsa veya idrarı koyu renkte ise 3-5 $\mathrm{mL} / \mathrm{kg}$ daha sıvı almalıdır (4). Tenisçiler antrenman veya müsabaka sirasinda ortalama sıcaklıklardaki bir ortamda $\left(<27^{\circ} \mathrm{C}\right)$ her saha değişimi sırasında $>200$ mL sıvı tüketmeli, daha yüksek sıcaklıklarda ise sıvı alımı 400 mL'nin üzerinde olmalıdır (29). Alınan sıvıların ortam sıcaklığından daha soğuk olması (15$22^{\circ} \mathrm{C}$ ) ve lezzetinin arttırılarak tatlandırılması sıvı replasmanını desteklemek için önerilir. Sıvılar, kolay tüketilebilecek, egzersizi en az kesintiye uğratacak şekilde, uygun kaplarda ve hacimde sunulmalıdır. Bir saatten uzun süren egzersiz sırasında alınan rehidrasyon çözeltisine sodyum eklenmesi (0.5$0.7 \mathrm{~g} / \mathrm{L}$ ), lezzeti ve sivi tutulumunu artırmada ve muhtemel hiponatremiyi önlemede avantajlı olabilir (30). Antrenmanlardan veya müsabakalardan önce ve sonra vücut ağırlığının rutin olarak izlenmesi, bireylerin uygun hidrasyon sağlamaları için iyi bir stratejidir. Ayrıca, idrar renginin izlenmesi hidrasyon durumunu değerlendirmenin basit bir yoludur. Ancak Amerikan Spor Hekimliği Koleji (American College of Sports Medicine-ACSM), idrar renginin genellikle öznel olduğunu ve kafa karıştırıcı olabileceğini belirtmiştir (28). Egzersiz sonrası rehidrasyonun sağlanması için her $1 \mathrm{~kg}$ vücut ağırlığı kaybına, sodyum içeren (20-50 mEq/L) 1-1.5 L sıvı tüketilmesi önerilmektedir (2,26). 
Bazı mineraller belirli koşullar altında sporcular için egzersiz kapasitesini ve/veya antrenman adaptasyonlarını arttırabilir (31). Sodyum, terle kaybedilen esansiyel elektrolit, hücre dışı sıvıda bulunan temel mineraldir ve tenisçilerin beslenmesinde tüketimini artırmak önemlidir (15). Tavsiye edilen alım önerisi antrenman/maç günlerinde besinlerle alıma ek olarak 1.5 g/L'dir (29). Sodyum yetersizliği yorgunluk, baş ağrısı, baş dönmesi, kas krampları ve yüksek ateşe yol açabilir (15). Egzersize bağlı kas kramplarının çok sayıda etkileyen faktörü olduğu, dehidrasyon ve elektrolit kaybının kas kramplarının tek nedeni olmadığ gösterilmiştir (11).

Potasyum sivı dengesini, sinir iletimini ve asitbaz dengesini düzenlemeye yardımcı olan bir elektrolittir. Bazı araştırmalar potasyumdaki aşırı artış veya düşüşlerin sporcuları kramplara yatkın hale getirebileceğini ileri sürmektedir. Tavsiye edilen potasyum alım önerisi günde 2000 mg’dır (31).

Kalsiyum kan pıhtılaşması ve sinir iletiminde rol oynar (31). Aynı zamanda yağ metabolizmasını da uyarır (32). Tavsiye edilen günlük alım miktarı (19-50 yaş) 1000 mg’dır. Besinlerle günlük alım miktarının yeterli olduğu durumlarda takviye alımı egzersiz performansı üzerinde ergojenik etki sağlamaz. Osteoporoza duyarlı sporcularda kalsiyum takviyesi kemik kütlesinin korunmasında yardımcı olabilir (31).

Demir, oksijen taşıyıcı olan kırmızı kan hücresindeki hemoglobinin önemli bir bileşenidir. Kaslara maksimum oksijen iletimi ve oksijenin etkin kullanımından dolayı sporcular anemi ve demir eksikliğine daha duyarlıdır (33). Tavsiye edilen günlük alım önerisi erkekler için 8 mg kadınlar için 18 mg’dır (19-50 yaş). Tavsiye edilen alımın yanı sıra demir emilimi de dikkate alınmalıdır (33,34). Besinlerde serbest veya hem grubuna bağlı olarak bulunan demir minerali ince bağırsak eritrosit hücreleri tarafindan emilir. Diyetle yeterli miktarda demir mineralinin alınamaması ve ince bağırsaktan yeterli emilimin sağlanamaması demir eksikliğine neden olmaktadır (35). Demir eksikliği sporcularda fiziksel performansın azalması ve egzersiz kapasitesinin düşmesi ile ilişkilidir. Özellikle kadın sporculardaki menstural kayıplar demir eksikliği riskinin değerlendirilmesinde dikkate alınması gereken önemli bir faktördür (36).

\section{SONUÇ VE ÖNERİLER}

Sporcunun sağlığı ve performansı, uygun bir beslenme programı ile doğrudan ilişkilidir. Tenis katılım düzeyi yüksek bir spor dalı olmasına karşın, tenis sporcularinin beslenme durumunu inceleyen çalışmalar ya da tenis branşına özgü beslenme önerileri içeren kaynaklar sinırlıdır. $\mathrm{Bu}$ nedenle tenis sporcularının beslenmesinde genel sporcu beslenmesi önerileri dikkate alınmaktadır. Fakat tenis diğer branşlardan farklı olarak; hız, çeviklik ve güç gibi anaerobik becerilerin, yüksek aerobik yeteneklerle bir arada kullanılmasına ihtiyaç duyan, kısa süreli, yüksek şiddetli, tekrarlayan hareketlerle interval bir spor olup, aynı zamanda dikkat, konsantrasyon ve koordinasyon gerektiren beceriye dayalı bir branştır. Ayrıca yoğun bir fikstür takvimi, sık seyahat etme durumu, oyunun oynandığı yüzey, oyun tarzı, sıcaklık, nem gibi çevresel koşullar, müsabaka sürelerinin önceden tahmin edilememesi gibi durumlar sporcunun hazırlığını, performansını, toparlanma süresini etkileyebilecek çeşitli zorluklar ortaya çlkartmakta ve sporcuya özel bir beslenme programını zorunlu kılmaktadır. Genel bir programdan ziyade, sporcunun antrenman planina uygun, amaca yönelik, bireyselleştirilmiş bir beslenme programı, antrenmana adaptasyonu sağlamak, performansı artırmak, toparlanmayı hızlandırmak, yaralanma riskini azaltmak ve hastalıkları önlemek için gerekli ve önemlidir. Ayrıca teorik bilime ve pratik saha uygulamalarına katkı sağlayacak, branşa özgü bilimsel çalışmalara ihtiyaç vardır.

Çıkar çatışması - Conflict of interest: Yazarlar çıkar çatışması olmadığını beyan ederler. - The authors declare that they have no conflict of interest. 


\section{KAYNAKLAR}

1. Pluim BM, Windler G. Epidemiology of Tennis Injuries. In: Giacomo GD, Ellenbecker TS, Kibler WB, editors. Tennis Medicine. Cham: Springer; 2018. p. 43-51.

2. Parker-Simmons S, Love P. Sports Nutrition for Tennis Players. In: Giacomo GD, Ellenbecker TS, Kibler WB, editors. Tennis Medicine. Cham: Springer; 2018. p. 56372.

3. Kolman NS, Kramer T, Elferink-Gemser MT, Huijgen $\mathrm{BCH}$, Visscher C. Technical and tactical skills related to performance levels in tennis: A systematic review. J Sports Sci. 2019;37(1):108-21.

4. Sanchez J, Mata F, Grimaldi M, Domínguez R. Nutritional and water needs. ITF Coaching and Sport Science. 2017;73(25):13-5.

5. Fleming JA, Naughton RJ, Harper LD. Investigating the nutritional and recovery habits of tennis players. Nutrients. 2018;10(4):443.

6. Périard JD, Girard O. Heat stress, hydration and heat illness in elite tennis players. In: Giacomo GD, Ellenbecker TS, Kibler WB, editors. Tennis Medicine. Cham: Springer; 2018. p. 573-87.

7. Torres-Luque G, Sánchez-Pay A, Belmonte JB, Ramón MM. Functional aspects of competitive tennis. J Hum Sport Exerc. 2011;6(3):528-39.

8. OjalaT, Häkkinen K. Effects of the tennis tournament on players' physical performance, hormonal responses, muscle damage and recovery. J Sports Sci Med. 2013;12(2):240-8.

9. Kovacs MS. Tennis physiology. Sports Med. 2007;37(3):189-98.

10. Kovacs M, Pluim B, Groppel J, CrespoM, Roetert EP, Hainline B, et al. Health, wellness and cognitive performance benefits of tennis. Medicine \& Science in Tennis. 2016;21(3):14-21.

11. Teodor DF. Nutrition guidelines for competitive tennis. Palestrica of the third millennium-Civilization and Sport. 2017;18(4):225-8.

12. Ranchordas MK, Rogersion D, Ruddock A, Killer SC, Winter EM. Nutrition for tennis: Practical Recommendations. J Sports Sci Med. 2013;12(2):211-24.

13. Smekal G, Duvillard SPV, Rihacek C, Pokan R, Hofmann $\mathrm{P}$, Baron R, et al. A physiological profile of tennis match play. Medicine \& Science in Sports \& Exercise. 2001;33(6):999-1005.

14. Ondrak KS, McMurray RG. Comparison of energy expenditure of youth playing tennis during practice and match settings. J Phys Act Health. 2016;13(1):21-3.

15. International Tennis Federation. Nutrition. Available at:https://www.itftennis.com/scienceandmedicine/ nutrition/eating-right.aspx Accessed Feb 4, 2019.
16. Mata F, Valenzuela PL, Gimenez J, Tur C, Ferreria D, Domínguez R, et al. Carbohydrate availability and physical performance: Physiological overview and practical recommendations. Nutrients. 2019;11(5):1084.

17. Kovacs MS. Carbohydrate intake and tennis: Are there benefits? Br J Sports Med. 2006;40(5):e13-e13.

18. Belski, R. Exercise nutrition. In: Belski R, Forsyth A, Mantzioris E, editors. Nutrition for Sport, Exercise and Performance. Australia: Allen \& Unwin; 2019. p. 185-195.

19. Thomas DT, Erdman KA, Burke LM. American College of Sports Medicine Joint Position Statement. Nutrition and athletic performance. Medicine \& Science in Sports \& Exercise. 2016;48(3):543-68.

20. Desbrow B, McCormack J, Burke LM, Cox GR, Fallon K, Hislop M, et al. Sports dietitians Australia position statement: Sports nutrition for the adolescent athlete. Int J Sport Nutr Exerc Metab. 2004;24(5):570-84.

21. Mantzioris E. Macronutrients. In: Belski R, Forsyth A, Mantzioris E, editors. Nutrition for Sport, Exercise and Performance. Australia: Allen \& Unwin; 2019. p. 83-107.

22. Phillips SM, Van Loon LJC. Dietary protein for athletes: From requirements to optimum adaptation. J Sports Sci. 2011;29(1):29-38.

23. Burke LM, Castell LM, Casa DJ, Close GL, Costa RJS, Desbrow B, et al. International Association of Athletics Federations Consensus Statement 2019: Nutrition for athletics. Int J Sport Nutr Exerc Metab. 2019;29(2):73-84.

24. Martinez IG, Skinner SK, Burd NA. Protein intake for optimal sports performance. In: Bagchi D, Sen CK, Nair S, editors. Nutrition and Enhanced Sports Performance. 2th ed. Academic Press; 2019. p. 461-70.

25. Kårlund A, Gómez-Gallego C, Turpeinen AM, Palo-oja OM, El-Nezami H, Kolehmainen M. Protein supplements and their relation with nutrition, microbiota composition and health: Is more protein always better for sports people?. Nutrients. 2019;11(4):829.

26. Kovacs MS, Baker LB. Recovery interventions and strategies for improved tennis performance. Br J Sports Med. 2014;48(1):i18-i21.

27. Shephard RJ. Factors influencing the optimal choice of sports beverages. In: Grumezescu AM, Holban AM, editors. Sports and Energy Drinks. Woodhead Publishing; 2019. p. 131-59.

28. Raizel R, Coqueiro AY, Bonvini A, Tirapegui J. Sports and energy drinks: Aspects to consider. In: Grumezescu AM, Holban AM, editors. Sports and Energy Drinks. Woodhead Publishing; 2019. p. 1-37.

29. Kovacs MS. A review of fluid and hydration in competitive tennis. Int J Sports Physiol Perform. 2008;3(4):413-23.

30. Convertino VA, Armstrong LA, Coyle EF, Mack GW, 
Sawka MN, Michael N, et al. ACSM Position Stand: Exercise and Fluid Replacement. Medicine \& Science in Sports \& Exercise. 1996;28(10) i-ix.

31. Kerksick CM, Wilborn CD, Roberts MD, Smith-Ryan A, Kleiner SM, Jäger R, et al. ISSN exercise \& sports nutrition review update: Research \& Recommendations. J Int Soc Sports Nutr. 2018;15(1):38.

32. Zemel MB, Role of dietary calcium and dairy products in modulating adiposity. Lipids. 2003;38(2):139-46.

33. Suedekum NA, Dimeff RJ. Iron and the athlete. Curr Sports Med Rep. 2005;4(4):199-202.
34. Whiting SJ, Barabash VA. Dietary reference intakes for the micronutrients: considerations for physical activity. Appl Physiol Nutr Metab. 2006;31(1):80-5.

35. Güleç Ş. Diyetten alınan ve kandaki demir mineralinin insan ince bağırsak hücre modelinde demir eksikliği anemisine etkisi. Bes Diy Der. 2018;46(2):107-17.

36. Mayer CM, Barker MK, Dirk P, Moore KM, McCrudden E, Karakochuk CD. Menstrual blood losses and body mass index are associated with serum ferritin concentrations among female varsity athletes. Appl Physiol Nutr Metab. 2020;45(7):723-30. 